\title{
PARIWISATA KREATIF BERBASIS INDUSTRI BATIK SEBAGAI UPAYA PENGEMBANGAN EKONOMI LOKAL KOTA PEKALONGAN
}

\author{
Creative Tourism Based on Batik Industry as an Effort to Local \\ Economic Development of Pekalongan
}

\section{Latifah $^{1}$ dan Maya Damayanti}

Diterima: 21 Oktober 2015 Disetujui: 9 Februari 2016

\begin{abstract}
Abstrak: Saat ini Kota Pekalongan dikenal sebagai kota batik, baik pada tingkat nasional maupun internasional melaluiadanya penetapan sebagai kota kreatif dunia berdasarkan pada seni dan kebudayaan batiknya. Batik merupakan salah satu industri kreatif berbasis pada kebudayaan yang telah menjadi komoditas ekonomi utama di Kota Pekalongan.. Batik sebagai industri kreatif juga mampu menciptakan adanya keterkaitan antar pelaku usaha seperti usaha pembuatan canting, usaha pewarna kain dan sebagainya. Sebagai pelengkap menjadi kota batik, Kota Pekalongan menyediakan destinasi wisata berupa Museum Batik dan dua sentra pengerajin batik. Atraksi wisata yang ditawarkan mempunyai nilai tambah karena wisatawan tidak hanya melihat proses tetapi dapat mempraktekannya secara langsung bagaimana proses pembuatan batik bersama dengan para pengejarin batik dan bersentuhan langung dengan alat dan bahan pembuatan batik. Atraksi wisata ini selain dapat menjadi nilai kompetensi bagi pariwisata Kota Pekalongan untuk meningkatkan jumlah kunjungan wisata juga tentu saja memberikan dampak bagi Kota Pekalongan. Dampak dari adanya atraksi wisata pariwisata kreatif berbasis industri batik ini dapat menjadi salah satu upaya dalam pengembangan ekonomi lokal Kota Pekalongan, karena telah mampu membuat keterkaitan antar sektor baik pariwisata maupun industri batik.
\end{abstract}

Kata kunci: Pariwisata Kreatif, Industri Batik, Pengembangan Ekonomi Lokal, Kota Pekalongan

Abstract: Currently, Pekalongan City is known as the city of batik. The recognition is both at national and international levels whereas Pekalongan has been acknowledged as a world creative city based on the art and culture of batik. Batik is an essential commodity in Indonesian creative industries and has been the major commodity of Pekalongan. Batik industry is also capable of creating an inter-business association like the canting making business and fabric dyes business. As a city of batik, Pekalongan is prepared as a tourist destination through the availability of Batik Museum and two centers of batik craftsmen. The attraction has been increasing because tourists do not only see the process but can practice on how to make batik along with the batik craftsmen and interact with the related tools and materials, and this is known as creative tourism. The impact of the creative tourism can become one of the efforts to the local economic development of Pekalongan because it has been able to make linkages between sectors in tourism and batik industry.

Keywords: Creative Tourism, Batik Industry, Local Economic Development, Pekalongan City

\footnotetext{
${ }^{1}$ Jurusan Perencanaan Wilayah dan Kota, Fakultas Teknik, Universitas Diponegoro
}

Korespondensi: latifah15@pwk.undip.ac.id 


\section{Pendahuluan}

Saat ini pariwisata semakin dianggap sebagai sebuah langkah yang sangat baik dalam upaya pembangunan ekonomi local (Booyens \& Gustav, 2010). Hal ini dikarenakan pariwisata mampu mendorong, merangsang, memelihara aktivitas usaha dan menciptakan lapangan pekerjaan melalui peran serta pemerintah lokal dan organisasi masyarakat sesuai dengan konsep pengembangan ekonomi lokal (Blakely dan Bradshaw, 2002). Pendapat serupa juga disampaikan oleh Incera \& Fernandez(2015) bahwa pariwisata dapat memberikan kontribusi terhadap pertumbuhan ekonomi regional, menyediakan pendapatan bagi penduduk serta bagi perusahaan lokal, dan sangat relevan dikembangkan di negara berkembang maupun negara maju.

Kegiatan dalam wisata menurut Yoeti (2010) terdiri dari something to see terkait dengan atraksi tujuan wisata, something to buy terkait dengan cinderamata dan something to do terkait dengan aktivitas yang dapat dilakukan di daerah wisata. Seiring dengan adanya perubahan paradigma wisata yaitu perubahan dari kegiatan wisata yang awalnya sekedar untuk memenuhi "something to see" kini bergeser menjadi kegiatan wisata yang mampu untuk memenuhi "something to do", (Suparwoko, 2010). Pergeseran paradigma pariwisata ini didasari oleh kegiatan pariwisata konvensional (mass tourism) yang berorientasi pada pertumbuhan ekonomi namun cenderung untuk menempatkan masyarakat (wisatawan) sebagai bagian dari proses penyediaan produk pariwisata dan bukan sebagai pihak yang semestinya difasilitasi untuk memperoleh pengalaman wisata (Kusworo, 2009).Sejalan dengan pergeseran pariwisata, perkembangan ekonomi juga mengalami pergeseran. Pergeseran ekonomi dimulai dari ekonomi pertanian, kemudian beralih menjadi ekonomi industri, dan saat ini mengalami pergeseran ke arah ekonomi informasi dan ekonomi kreatif(Departemen Perdagangan Republik Indonesia, 2008).

Pariwisata kreatif hadir sebagai bentuk baru wisata yang memberikan pengalaman mengenai karakter budaya seperti yang diungkapkan oleh Jarábková dan Hamada (2012) bahwa wisata kreatif melibatkan pengunjung untuk berpartisipasi secara aktif dalam penciptaan produk dan mendapatkan pengalaman otentik berupa belajar tentang seni, warisan budaya dan karakter khusus dari tempat tertentu.

Menurut Richards \& Wilson(2006) dalam (Wurzburger \& Dkk, 2008) karena pariwisata kreatif berbasis pada seni budaya, karakter daerah dan kerajinan khas suatu daerah (industri kreatif) maka pariwisata ini akan sekaligus berupaya dalam memasarkan produk lokal secara lebih efektif, merangsang pertumbuhan outlet-outlet kerajinan baru dan melindungi lapangan pekerjaan yang berbasis lokalitas, sehingga pariwisata kreatif tidak hanya menjual pengalaman dari budaya suatu tempat tetapi juga pariwisata yang mendukung identitas daerah tujuan wisata yang dapat meningkatkan konsumsi kebudayaan lokal dan kreativitas lokal.

Konsep pariwisata kreatif ini sejalan dengan Kota Pekalongan yang mempunyai kebudayaan batik dan telah berupaya menciptakan wisata berbasis batik melalui destinasi wisata Museum Batik dan Kampung Batik. Penelitian ini bertujuan untuk mengidentifikasi pariwisata kreatif berbasis industri batik dan dampaknya dalam mendukung pengembangan ekonomi lokal kota pekalongan. Adapun sasaran untuk mencapai tujuan tersebut adalah sebagai berikut:

1. Mengidentifikasi karakteristik industri batik sebagai dasar dalam pengembangan pariwisata kreatif Kota Pekalongan;

2. Mengidentifikasi karakteristik Kampung Batik Kauman, Kampung Batik Pesindon dan Museum Batik Pekalongan sebagai studi kasus penawaran pariwisata kreatif;

3. Mengidentifikasi atraksi wisata kreatif berbasis industri batik Kota Pekalongan sebagai aspek penawaran wisata kreatif; 
4. Menganalisis persepsi wisatawan terhadap elemen pariwisata kreatif berbasis industri batik dan preferensi wisatawan terhadap kegiatan wisata kreatif di Kota Pekalongan sebagai aspek permintaan pariwisata kreatif.

5. Menganalisis dampak pariwisata kreatif berbasis industri batik Kota Pekalongan yang dihasilkan terhadap upaya pengembangan ekonomi lokal Kota Pekalongan.

Ruang lingkup wilayah penelitian ini adalah Kota Pekalongan, dengan lokasi amatan berada pada tiga titik yaitu Museum Batik Pekalongan, Kampung Batik Kauman dan Kampung Batik Pesindon. Berikut adalah peta lokasi amatan penelitian;

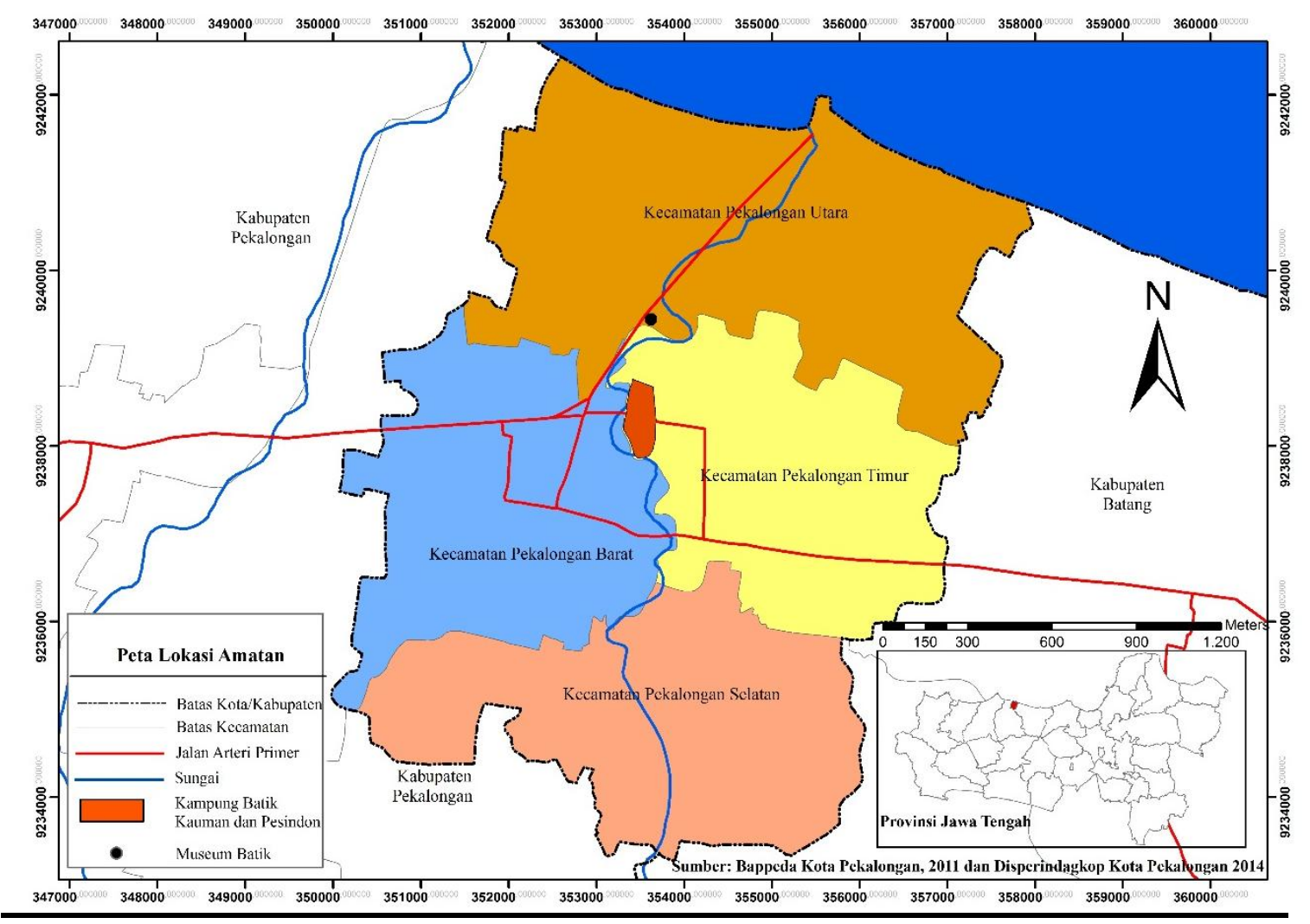

Gambar 1. Lokasi Amatan

\section{Kajian Literatur}

\section{Pariwisata Kreatif sebagai Upaya Pengembangan Ekonomi Lokal}

Menurut UNESCO (2006)Pariwisata kreatif adalah generasi baru pariwisata. UNESCO menjelaskan bahwa generasi pertama pariwisata adalah wisata pantai, di mana orang-orang datang ke tempat wisata untuk relaksasi dan rekreasi, yang kedua adalah wisata budaya yang berorientasi pada wisata museum dan budaya. Pariwisata kreatif melibatkan lebih banyak interaksi, di mana wisatawan memiliki pendidikan, emosional, interaksi sosial, dan sikap partisipatif dengan lingkungan, budaya, serta masyarakat lokal. Banyak kegiatan yang dapat menjadi dasar dalam pariwisata kreatif, seperti memasak, melukis, musik, fotografi, kerajinan, tari dan sebagainya (Smith, 2009 dalamIlincic, 2014) Ilincic, 2014), namun kegiatan tersebut harus dihubungkan dengan daerah tujuan wisata tempat dimana kegiatan tersebut diselenggarakan(Richards \& Wilson, 2006)seperti yang 
telah dilakukan oleh spanyol yang menjadikan memasak makanan tradisional sebagai dasar dalam kegiatan pariwisata kreatif. Pariwisata kreatif lebih dari sekedar pemberian pengalaman belajar (Raymond, 2007 dalam Ilincic, 2014), serta harus juga melibatkan dengan karakter daerah tujuan wisata, pemberian makna dan identitas bagi daerah tujuan wisata (Richards, 2011 dalamIlincic, 2014).

Pengembangan pariwisata kreatif memiliki dampak yang positif seperti yang terjadi di kota kecil di Bulgaria yaitu (Olson dan Ivanov 2010)

1. Membangkitkan kembali seni kerajinan, tradisi, musik dan kostum lokal;

2. Memperbaharui kebanggan penduduk setempat terhadap warisan budaya yang dimiliki;

3. Mempopulerkan adat istiadat dan tradisi setempat;

4. Melestarikan seni dan kerajinan kuno;

5. Melestarikan warisan budaya;

6. Mengintegrasikan pelestarian warisan budaya dengan pengembangan masyarakat, pendidikan dan pariwisata serta mendorong dalam meningkatkan pengetahuan dan kesadaran masyarakat terhadap pentingnya melesatariakn warisan budaya;

7. Menciptakan lapangan pekerjaan dan meningkatkan pendapatan industri kreatif;

8. Menyebarkan tingkat kreativitas;

9. Meningkatkan daya saing tujuan wisata.

Berdasarkan uraian manfaat pariwisata kreatif yang disampaikan oleh Olson dan Ivanov. (2010), dapat diketahui bahwa salah satu manfaat dari adanya pengembangan pariwisata kreatif adalah menciptakan lapangan pekerjaan dan meningkatkan pendapatan industri kreatif.

Pariwisata kreatif yang berbasis pada kebudayaan juga tentunya akan memberikan pengaruh terhadap kondisi perekonomian seperti yang disampaikan oleh Creative City Network of Canada (2005) bahwa kota-kota yang mengadopsi budaya lokal dan menjadikannya sebagai basis industrinya akan memperoleh manfaat ekonomi yang positif bagi masyarakatnya, seperti menciptakan pertumbuhan lapangan pekerjaan, menciptakan keterkaitan antara seni dan bisnis, merevitalisasi perkotaan, menarik tenaga kerja terampil dan menciptakan perputaran bisnis. Hal ini tentu saja akan memberikan pengaruh atau manfaat terhadap pengembangan ekonomi lokal Kota Pekalongan.

Menurut Susanti (2013) pengembangan ekonomi lokal adalah upaya pemerintah daerah bersama masyarakat dalam membangun kesempatan-kesempatan ekonomi yang cocok dengan SDM, dan mengoptimalkan pemanfaatan sumber daya alam dan kelembagaan secara lokal. Indikator keberhasilan pengembangan ekonomi lokal menurut Supriyadi (2007) dalam Prasetyo(2014) adalah sebagai berikut;

1. Perluasan kesempatan bagi masyarakat dalam kesempatan kerja dan usaha;

2. Perluasan kesempatan bagi masyarakat untuk meningkatkan pendapatan;

3. Keberdayaan lembaga usaha mikro dan kecil dalam proses produksi dan pemasaran;

4. Adanya pola kemitraan antara pemerintah daerah, usaha dan swasta serta masyarakat lokal.

Selanjutnya menurut (Blair, 1995)indikator yang dapat dijadikan sebagai tolak ukur keberhasilan pengembangan ekonomi lokal adalah

1. Peningkatan pendapatan masyarakat;

2. Peningkatan kualitas hidup meliputi transportasi, pendidikan dan budaya.

\section{Industri Kreatif sebagai dasar Pengembangan Pariwisata Kreatif}

Sesuai dengan pendapat Olson dan Ivanov (2010) bahwa pariwisata kreatif berbasis pada kegiatan kreatif, maka dalam penelitian ini industri kreatif batik akan dijadikan sebagai dasar dalam pengembangan pariwisata kreatif di Kota Pekalongan. Istilah ekonomi kreatif 
pertama kali digunakan pada tahun 2001 oleh John Howkins dalam karyanya yang berjudul The Creative Economy: How People Make Money from Ideas (Vesela \& Klimova, 2014). Pengertian industri kreatif yang diterapkan di Indonesia adalah industri yang berasal dari pemanfaatan bakat individu untuk menciptakan kesejahteraan serta lapangan pekerjaan melalui penciptaan dan pemanfaatan daya kreasi dan daya cipta tersebut (Departemen Perdagangan Republik Indonesia, 2008). Terdapat tiga arah pengembangan industri kreatif yaitu industri yang berbasis pada pada lapangan usaha kreatif dan budaya (creative cultural indusrty), lapangan usaha kreatif (creative industri) dan hak kekayaan intelektual (copyright industry) (Departemen Perdagangan Republik Indonesia, 2008).

Berikut ini adalah pengaruh penggabungan industri kreatif dengan pariwisata menurut OECD (2014)

1. Meningkatkan permintaan pariwisata dan/atau menghasilkan pengalaman wisata baru dan menarik;

2. Membangun citra melalui peningkatan penerapan kreativitas;

3. Mengembangkan soft infrastructure seperti bisnis usaha kecil kreatif, ruang kreatif, kursus dan pelatihan, kafe dan restoran yang berfungsi untuk memungkinkan adanya interaksi produsen dan konsumen;

4. Menarik bakat kreatif dengan meningkatkan kualitas hidup, merangsang inovasi dengan menambahkan dukungan kreativitas dan teknologi baru untuk pengembangan pariwisata dan menantang industri kreatif untuk menemukan caracara baru dalam mengelola pariwisata serta meningkatkan kinerja bisnis pariwisata.

\section{METODE PENELITIAN}

Metode penelitian yang digunakan dalam penelitian pariwisatakreatif berbasis industri batik sebagai upaya dalam pengembangan ekonomi lokal Kota Pekalongan adalah kualitatif dan kuantitatif atau campuran. Metode yang digunakan adalah metode campuran convergen parallel yaitu metode yang mencampurkan data dan analisis kualitatif dan kuantitatif(Creswell, 2010). Penggunaan metode ini adalah dengan cara mengumpulkan data kualitatif dan data kuantitatif secara bersamaan. Setelah kedua data tersebut terkumpul peneliti kemudian melalukan kombinasi atau penggabungan dari dua data yang telah diperoleh yaitu data kualitatif dan data kuantitatif. Penggabungan kedua data ini dilakukan pada saat melakukan analisis, pembahasan dan interpretasi hasil. Kedua data memiliki porsi yang sama besar, artinya tidak menitik beratkan pada salah satu data. Penggabungan kedua data tersebut bertujuan untuk saling mendukung antar kedua data tersebut.

\section{Teknik pengumpulan data}

Teknik pengumpulan data yang digunakan dalam penelitian ini yaitu teknik pengumpulan data sekunder dan primer.

Teknik Pengumpulan Data Sekunderberupa pencarian data yang bersumber dari instansi terkait dengan penelitian yang dilakukan di instansi yang terkait dengan upaya untuk mendukung menjawab permasalahan yang telah dirumuskan dan memberikan faktafakta tentang pariwisata kreatif dan industri batik di Kota Pekalongan. Adapun instansiinstansi yang mendukung dalam pengumpulan data ini adalah BPS Kota Pekalongan, Disperindagkop Kota Pekalongan, Dishubparbud Kota Pekalongan dan Unit Pengelola Museum Batik Pekalongan

Teknik Pengumpulan Data Primer merupakan teknik pengumpulan dimana informasi yang diperoleh berasal dari sumber-sumber primer, yaitu peneliti langsung terjun mencatat 
kejadian-kejadian di lapangan. Teknik pengumpulan data primer yang akan digunakan dalam penelitian ini yaitu kuesioner, wawancara dan observasi lapangan.

\section{Teknik Sampling}

Teknik penarikan sampel dalam penelitian ini dibagi menjadi dua bagian, yaitu penarikan sampel untuk wisatawan dan penarikan sampel untuk pelaku pariwisata kreatif berbasis industri batik di Kota Pekalongan. Berikut ini adalah penjelasan untuk masingmasing teknik penarikan sampel yang dilakukan.

Teknik yang dilakukan dalam penarikan sampel untuk wisatawan adalah dengan menggunakan non probability sampling teknik ini memungkinkan peluang sesorang untuk menjadi responden tidak diketahui. Metode yang digunakan adalah accidental sampling.

Penentuan sampel wisatawan pada Museum Batik Pekalongan dan Kampung Batik menggunakan rumus Slovin dengan Populasi adalah rata-rata kunjungan tiap minggunya yaitu sebesar 261 wisatawan untuk Museum Batik dan 50 untuk Kampung Batik, berikut adalah hasil perhitungan sampel yang telah dilakukan;

Tabel 1. Jumlah Sampel Wisatawan

\begin{tabular}{clr}
\hline Nomor & \multicolumn{1}{c}{ Responden } & Jumlah \\
\hline 1 & Museum Pelajar & 43 \\
2 & Museum Dewasa & 29 \\
3 & Kampung Batik Pesindon Pelajar & 9 \\
4 & Kampung Batik Pesindon Dewasa & 11 \\
5 & Kampung Batik Kauman Pelajar & 4 \\
6 & Kampung Batik Kauman Dewasa & 9 \\
& Jumlah & 105 \\
\hline
\end{tabular}

Sumber: Hasil Analisis, 2015

Penentuan sampel berikutnya adalah untuk pelaku wisata kreatif berbasis industri batik. Penentuan sampel yang dilakukan menggunakan metode non probability melalui teknik purposive sampling. Penggunaan teknik purposive sampling ini didasarkan pada pertimbangan peneliti terhadap anggota sampel yang dianggap dapat mewakili karakteristik populasi dan yang dianggap mengetahui bagaimana kondisi pariwisata kreatif berbasis industri batik Kota Pekalongan. Berdasarkan pada teknik purposive sampling tersebut didapatkan sampel untuk pelaku wisata sebagai berikut.

Tabel 2. Jumlah Sampel Pelaku Wisata Kreatif Batik Kota Pekalongan

\begin{tabular}{clc}
\hline Nomor & \multicolumn{1}{c}{ Informan } & Jumlah \\
\hline 1 & Instansi Disperindagkop & 1 \\
2 & Instansi Dishubparbud & 1 \\
3 & Pengusaha Batik Penyedia Jasa Wisata Kreatif & 3 \\
4 & Pengelola Kampung Batik & 2 \\
5 & Pengelola Museum Batik & 1 \\
& Jumlah & 8
\end{tabular}

Sumber: Hasil Analisis, 2015 


\section{HASIL PEMBAHASAN}

Hasil penelitian merupakan karakteristik pariwisata kreatif berbasis industri batik dan dampaknya terhadap pengembangan ekonomi lokal Kota Pekalongan.

\section{Analisis Batik Sebagai Industri Kreatif Berbasis Budaya dan pengaruhnya Terhadap Pengembangan Ekonomi Lokal}

Sebagai industri kreatif yang berbasis pada lapangan usaha kreatif dan kebudayaan, industri batik memiliki pengaruh yang cukup kuat bagi Kota Pekalongan. Hal ini dikarenakan batik telah menjadi sumber lapangan pekerjaan bagi sebagian besar masyarakat Kota Pekalongan umumnya dan masyarakat di dua kampung batik pada khususnya.

Pengembangan batik di Kota Pekalongan telah melibatkan para stakeholder lokal diantaranya masyarakat sebagai pengusaha dan pekerja batik, pemerintah sebagai pembina usaha batik, institusi pendidikan sebagai pengembang inovasi dan teknologi batik serta lembaga keuangan seperti koperasi dan bank. Berikut adalah skema keterkaitan batik sebagai industri kreatif berbasis budaya Kota Pekalongan

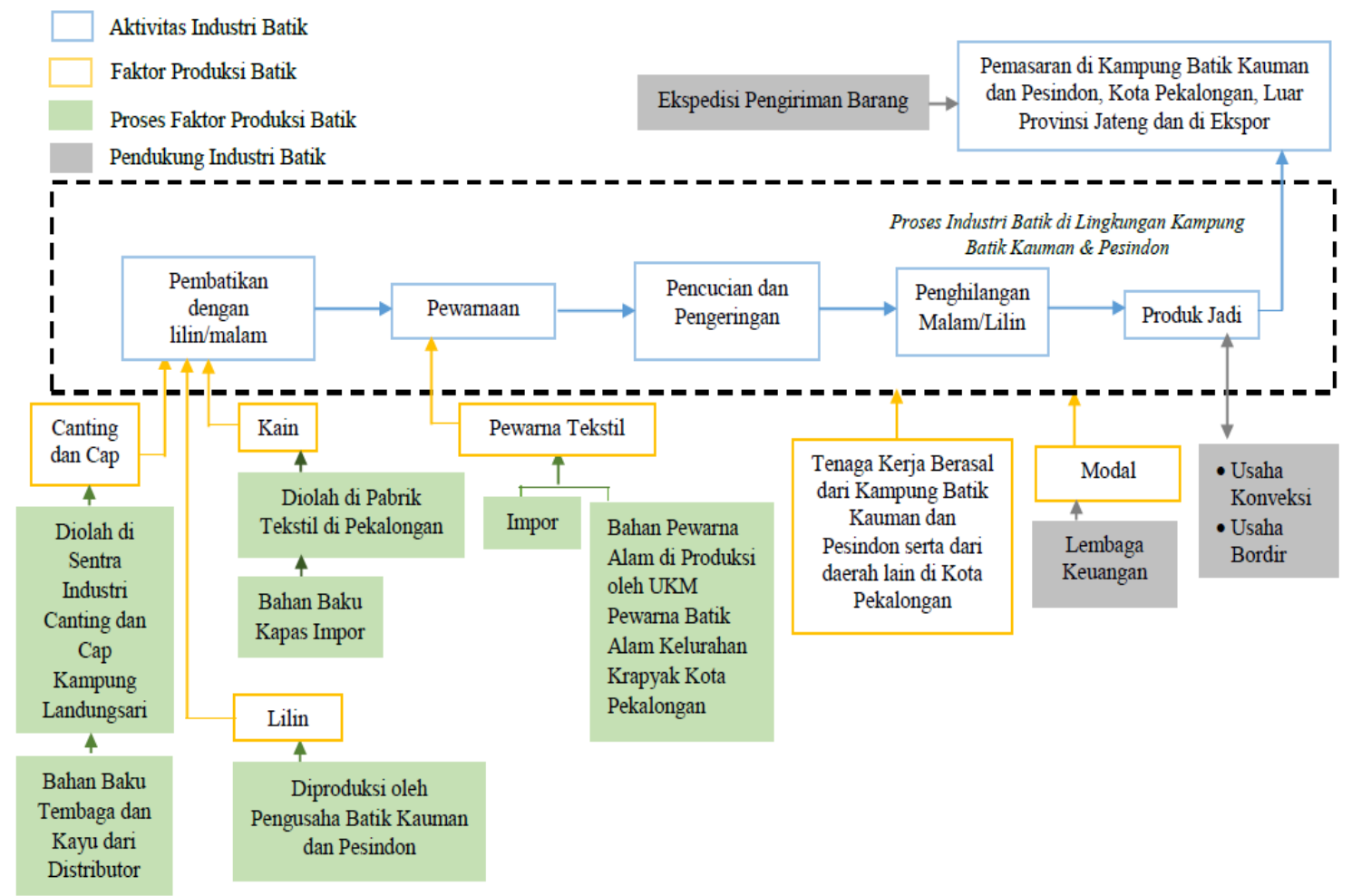

Sumber: Hasil Analisis Penulis, 2015

Gambar 2. Skema Keterkaitan Batik Sebagai Industri Kreatif 
Pengembangan industri batik Kota Pekalongan dilakukan melalui dua pendekatan yaitu pendekatan sebagai budaya dan sebagai industri. Pendekatan pengembangan industri batik ini merupakan nilai keunikan dari batik Kota Pekalongan, karena melalui dua pendekatan pengembangan ini mampu menciptakan nilai kompetensii bagi batik Kota Pekalongan jika dibandingkan dengan batik wilayah lain. Batik sebagai budaya berarti batik merupakan cerminan masyarakat Kota Pekalongan, artinya batik merupakan sebuah kebanggaan bagi Kota Pekalongan dan memiliki nilai untuk terus dilestarikan. Batik merupakan komoditas seni dan budaya yang berasal dari potensi lokal sehingga akan lebih melibatkan masyarakat lokal, hal ini dapat dilihat dari proses pembuatan batik yang hanya bisa dikerjakan oleh orang Pekalongan.

Semua pegawai dari pekalongan, karena orang Pekalongan nya yang sudah mengerti proses dari awal sampai akhir menjadi batik. Bagian proses untuk membuat motif menggunakan canting itu sulit, jadi hanya orang Pekalongan yang bisa. Karena usaha batik ini turun temurun, jadi hanya orang-orang yang asli pekalongan yang bisa. kalau orang luar pekalongan itu sulit, karena belum faham batiknya itu seperti apa. (W/PS/I/5 53-61)

Batik sebagai industri di Kota Pekalongan telah mampu membentuk jaringan rantai nilai dalam proses produksi hingga pemasarannya, meskipun masih terdapat beberapa bahan-bahan yang harus diimpor karena keterbatasan penyediaannya seperti kapas untuk kain dan pewarna kain. Rantai nilai tersebut diantaranya usaha pembuatan canting, usaha pembuatan pewarna alam, konveksi, bordir, pengemasan hingga jasa ekspedisi pengiriman barang. Batik sebagai industri juga membuat para pengusaha batik melakukan inovasi dalam produknya melalui beberapa cara, diantaranya adalah melakukan kreasi terhadap warna, pola motif dan desain pakaian agar batik yang diproduksi dapat lebih mengikuti perkembangan tren sehingga tetap memiliki pasar.

\section{Analisis Industri Batik Sebagai Dasar Dalam Pariwisata Kreatif Kota Pekalongan}

\section{Analisis Penawaran}

Atraksi wisata yang ditawarkan di Museum Batik Pekalongan, Kampung Batik Kauman dan Kampung Batik Pesindon merupakan jenis atraksi wisata kreatif, hal ini dikarenakan atraksi yang ada sudah mampu menjadikan karakteristik atau identitas Kota Pekalongan yaitu batik sebagai komponen utama dalam atraksi wisata tersebut, kemudian juga atraksi wisata yang disediakan memberikan kesempatan yang lebih kepada wisatawan untuk bertinteraksi secara langsung dengan lingkungan seperti pengusaha industri batik seta akat dan bahan pembuatan batik, sehingga dapat merasakan pengalaman secara langsung. Atraksi wisata di Museum Batik Pekalongan, Kampung Batik Kauman dan Kampung Batik Pesindon, tidak lagi hanya berfokus pada pemenuhan kebutuhan something to see dalam wisatanya, namun juga telah menggabungkan wisata dengan industri batik sehingga atraksi wisata yang ada juga memenuhi something to do yaitu dengan mengikuti kegiatan pelatihan batik dan something to buy, sehingga dengan demikian masyarakat lokal yang terdiri dari pengusaha batik, maupun pekerja batik dan usaha turunan batik seperti alat dan bahan membatik akan lebih merasakan manfaat dari adanya pariwisata kreatif ini.

Berwisata ke Museum Batik Pekalongan, Kampung Batik Kauman dan Kampung Batik Pesindon, wisatawan akan ditawarkan beberapa kegiatan dimulai dari pengenalan batik itu sendiri seperti motif, arti lambang, sejarah dan proses pengerjaan, kemudian akan dilanjutkan dengan kegiatan praktek belajar membatik bersama para pekerja batik jika di kampung batik atau bersama pemandu wisata jika di museum. Setelah pengenalan batik dan praktek membatik, wisatawan biasanya akan segera melakukan kegiatan wisata berbelanja. 
Aktivitas produksi industri batik telah mampu menjadi sebuah daya tarik wisata kreatif. Hampir Keseluruhan dalam rangkaian proses produksi batik dapat dijadikan sebagai aktivitas wisata kreatif seperti pembuatan motif dengan malam, canting dan cap, penghilangan malam, pewarnaan kain. Berdasarkan penawaran wisata yang ada didapatkan hasil karakteristik kegiatan wisata yang diminati wisatawan. Preferensi wisatawan ini dapat menjadi sebuah gambaran bagi pemerintah setempat untuk meningkatkan kualitas pada masing-masing kegiatan wisata sehingga setiap kegiatan wisata kreatif yang ada dapat diminati oleh wisatawan.

\section{Analisis Preferensi Wisatawan Terhadap Wisata Kreatif Yang Ditawarkan}

Berdasarkan pada hasil survei terhadap 105 responden, didapatkan karakteristik atraksi wisata yang diminati oleh wisatawan, berikut adalah hasilnya;

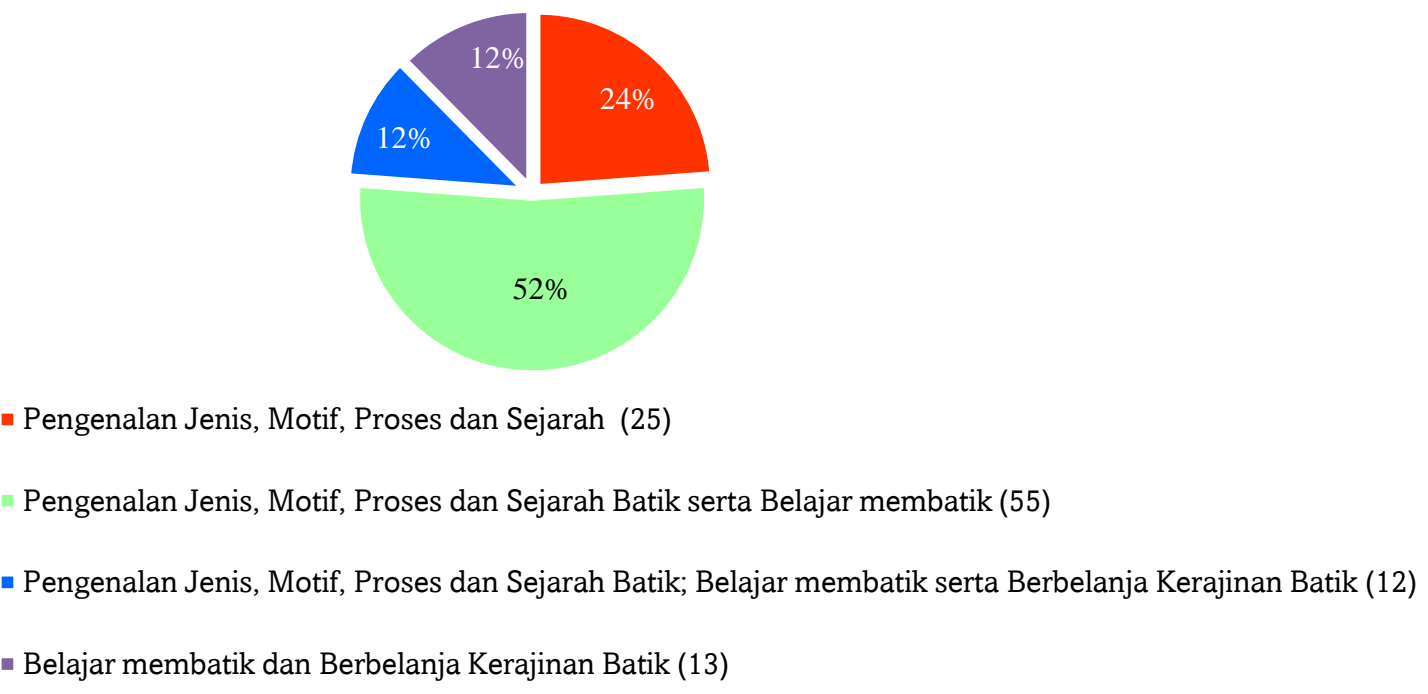

Sumber: Hasil Analisis Penulis, 2015

Gambar 3. Persentase Karakteristik Preferensi Wisatawan Terhadap Atraksi Wisata Yang Ditawarkan

Berdasarkan hasil analisis dapat diketahui bahwa dari beberapa atraksi wisata yang ditawarkan, atraksi wisata yang cukup diminati adalah kegiatan pengenalan jenis, motif, proses dan serajah batik serta belajar membatik yaitu sebesar $52 \%$, artinya adalah dari atraksi wisata yang disediakan, kegiatan yang memberikan pengalaman secara otentik tentang membatik, dan kegiatan yang memberikan kesempatan kepada wisatawan untuk belajar tentang batik dan karakter daerah merupakan kegiatan yang paling diminati sehingga wisata Museum Batik, Kampung Batik Kauman dan Kampung Batik Pesindon sudah dapat dikembangkan untuk menjadi wisata kreatif yaitu kegiatan wisata yang lebih dari sekedar pemberian pengalaman belajar namun juga melibatkan dengan karakter daerah tujuan wisata, pemberian makna dan identitas bagi daerah tujuan wisata.

Menurut survei terhadap pengelola wisata, baik pengelola museum maupun pengusaha penyedia jasa wisata di kampung batik, kegiatan pembelajaran batik ini selain diminati juga merupakan kegiatan yang cukup memberikan dampak bagi industrri batik secara luas. Hal ini dikarenakan dalam proses kegiatan wisata terdapat beberapa alat dan 
bahan yang wajib disediakan setiap ada kunjungan seperti canting, malam dan kain sehingga melalui kegiatan wisata ini dapat memberikan dampak peningkatan penghasilan bagi industri alat dan bahan pembuatan batik.

Hasil survei dan analisis juga menunjukkan bahwa melalui pariwisata di Museum Batik, Kampung Batik Kauman dan Kampung Batik Pesindon juga dapat meningkatkan penjualan hasil dari kerajinan batik. Hal ini dapat diketahui dari banyaknya wisatawan yang melakukan kegiatan wisata berbelanja batik yaitu sebesar $12 \%$ wisatawan melakukan kegiatan pengenalan jenis, motif, proses dan serajah batik; belajar membatik dan berbelanja batik, dan sebesar $12 \%$ melakukan kegiatan belajar membatik dan berbelanja kerajinan batik.

\section{Analisis Persepsi Wisatawan Terhadap Komponen Permintaan Wisata Kreatif Berbasis Industri Batik Kota Pekalongan.}

Analisis persepsi wisatawan ini bertujuan untuk mengetahui penilaian wisatawan terhadap komponen-komponen permintaan wisata kreatif. analisis ini akan mengukur apakah pariwisata yang disediakan sudah cukup memenuhi permintaan pariwisata yang diinginkan, sehingga apabila permintaan dan penawaran itu sudah sesuai akan menciptakan dampak yang berpengaruh pada pengembangan ekonomi lokal Kota Pekalongan. Berdasarkan analisis ini akan diketahui komponen permintaan pariwisata kreatif sesuai dengan permintaan, sehingga dapat menjadi masukan dalam upaya pengembangan pariwisata yang nantinya tentu saja akan berpengaruh terhadap pengembangan ekonomi lokal Kota Pekalongan.

Tabel 3.Analisis Persepsi Wisatawan Terhadap Aspek Permintaan Wisata Kreatif

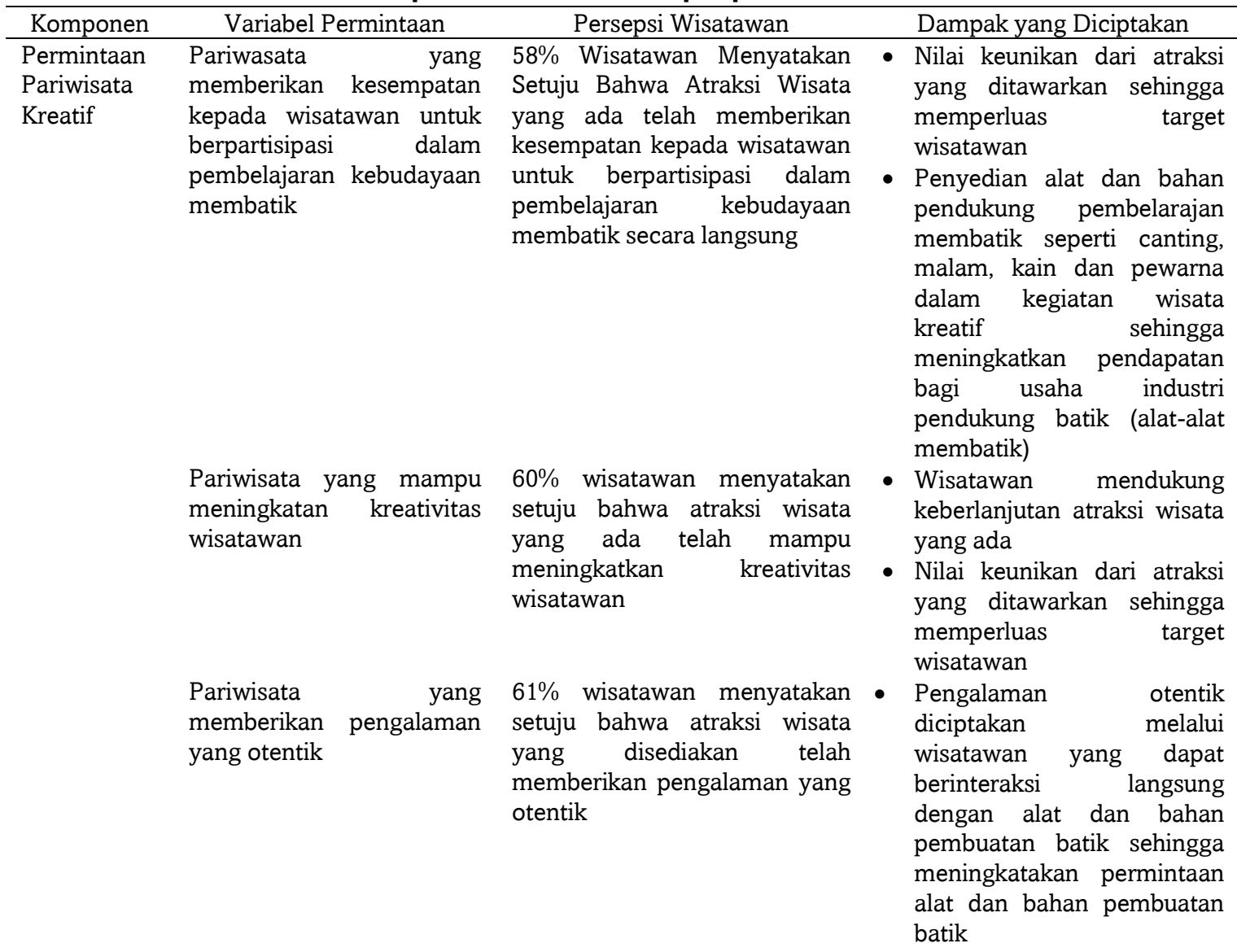




\begin{tabular}{|c|c|c|c|}
\hline Komponen & Variabel Permintaan & Persepsi Wisatawan & Dampak yang Diciptakan \\
\hline & $\begin{array}{l}\text { Pariwisata yang } \\
\text { memberikan kesempatan } \\
\text { kepada wisatawan untuk } \\
\text { berinteraksi dengan } \\
\text { pengerajin/seniman batik } \\
\text { secara langsung }\end{array}$ & $\begin{array}{lr}43 \% \text { wisatawan menyatakan } \\
\text { setuju bahwa atraksi wisata } \\
\text { yang disediakan telah } \\
\text { memberikan kesempatan untuk } \\
\text { berinteraksi r dengan } \\
\text { seniman/pengerajin } \\
\text { secara langsung }\end{array}$ & $\begin{array}{l}\text { - Memberikan kesempatan } \\
\text { kepada pengerajin/pekerja } \\
\text { batik untuk mendapatkan } \\
\text { penghasilan tambahasan } \\
\text { dari menjadi tutor wisata } \\
\text { kreatif belajar batik }\end{array}$ \\
\hline & $\begin{array}{l}\text { Pariwisata yang } \\
\text { memberikan pengalaman } \\
\text { yang baru dan berbeda }\end{array}$ & $\begin{array}{l}56 \% \text { wisatawan menyatakan } \\
\text { setuju bahwa atraksi wisata } \\
\text { yang disediakan telah } \\
\text { memberikan pengalaman yang } \\
\text { baru dan berbeda bagi } \\
\text { wisatawan }\end{array}$ & $\begin{array}{lr}\text { - Nilai keunikan dari atraksi } \\
\text { yang ditawarkan } & \text { sehingga } \\
\text { memperluas } & \text { target } \\
\text { wisatawan } & \end{array}$ \\
\hline & $\begin{array}{l}\text { Pariwisata yang } \\
\text { memberikan pengetahuan } \\
\text { tentang identitas dan } \\
\text { karakter Kota Pekalongan }\end{array}$ & $\begin{array}{l}56 \% \text { wisatawan menyatakan } \\
\text { setuju bahwa atraksi wisata } \\
\text { yang disediakan telah } \\
\text { memberikan pengetahuan } \\
\text { tentang karakter dan identitas } \\
\text { Kota Pekalongan }\end{array}$ & 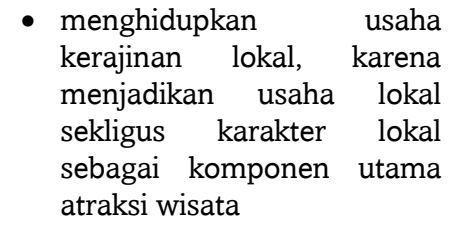 \\
\hline & $\begin{array}{l}\text { Pariwisata yang sekaligus } \\
\text { upaya pelesatarian budaya }\end{array}$ & $\begin{array}{l}55 \% \text { menyatakan sangat setuju } \\
\text { bahwa atraksi wisata yang ada } \\
\text { merupakan kegiatan wisata } \\
\text { yang sekaligus melestarikan } \\
\text { budaya }\end{array}$ & $\begin{array}{l}\text { - mendukung } \\
\text { keberlangsungan usaha } \\
\text { lokal, melalui batik sebagai } \\
\text { atraksi wisata yang sekaligus } \\
\text { merupakan kebudayaan dan } \\
\text { sektor ekonomi }\end{array}$ \\
\hline
\end{tabular}

Sumber: Hasil Analisis Penulis, 2015

\section{Analisis Tingkat Kesempatan Atau Penyerapan Tenaga Kerja}

Kegiatan wisata kreatif Kota Pekalongan yang menjadikan batik sebagai dasar dalam atraksi dan kegiatan wisatanya memberikan keuntungan bagi orang asli Kota Pekalongan, hal ini dikarenakan batik yang menjadi dasar dalam atraksi wisata merupakan kebudayaan dan kerajinan asli Kota Pekalongan, sehingga masyarakat Kota Pekalongan akan lebih dilibatkan dan menerima manfaatnya. Bentuk manfaat dari pengembangan pariwisata kreatif berbasis industri batik adalah peningkatan kesempatan kerja karena melalui batik sebagai dasar pengembangan wisata maka akan mendukung keberlangsungan usaha batik di Kota Pekalongan. Dukungan terhadap keberlangsungan usaha lokal melalui pariwisata kreatif ini dapat dilihat dari aspek peningkatan penjualan atau produksi batik. Peningkatan penjualan dan produksi akan berpengaruh juga pada peningkatan jumlah tenaga kerja. Hal inilah yang menjelaskan bahwa melalui pengembangan pariwisata kreatif akan memberikan dampak pada peningkatan penyerapan tenaga kerja. Penyerapan tenaga kerja ini dikarenakan untuk mengerjakan batik tulis perlu waktu sekitar tiga sampai enam bulan, dan untuk batik cap sekitar tujuh sampai dua puluh hari sehingga untuk mencapai target pesanan batik tersebut, para pengusaha batik akan menambah tenaga kerjanya.

Pariwisata kreatif yang memberikan kesempatan kepada wisatawan untuk memperoleh pengalaman secara otentik juga menyebabkan penyedia jasa wisata seperti Museum Batik dan pemilik galeri batik di Kampung Batik Kauman dan Kampung Batik Pesindon menyediakan alat dan bahan pembuatan batik untuk keperluan wisatawan. Penyediaan alat dan bahan ini akan berpengaruh terhadap naiknya permintaan alat seperti canting, dan malam serta bahan yaitu kain dan pewarna. Penyediaan alat dan bahan semuanya didatangkan dari pengusaha lokal, seperti canting yang didatangkan dari para pengerajin di Kampung Canting Landungsari dan Kuripan. Adanya kegiatan wisata kreatif membuat para pengerajin canting mendapatkan pasar lain yaitu menyediakan untuk kegiatan wisata dan cinderamata selain menyediakan canting untuk kepentingan industri 
batik, sehingga memberikan kesempatan kerja bagi masyarakat lokal untuk ikut memperoleh pekerjaan dari pembuatan canting ini.

\section{Analisis Pendapatan Pelaku Usaha Kreatif (Industri Batik dan Wisata Kreatif)}

Kegiatan wisata kreatif berbasis pada industri batik yang selain merupakan karakter dan indentitas kota juga merupakan sektor ekonomi unggulan bagi Kota Pekalongan membuat pariwisata kreatif berbasis indutri batik ini akan sekaligus mendukung keberlanjutan usaha lokal indunstri batik dan menghasilkan peningkatan pendapatan yaitu pendapatan dari produksi batik itu sendiri sebagai sesuatu yang dibeli saat berwisata dan pendapatan dari penyediaan jasa wisata kreatif belajar batik. Pendapatan melalui penyediaan jasa wisata kreatif didapatkan dari biaya wisata belajar membatik yang diikuti oleh wisatawan. Adapun untuk peningkatan pendapatan dari peningkatan penjualan batik terjadi karena melalui promosi kegiatan wisata belajar batik telah terjadi peningkatan penjualan batik, seperti yang disampaikan oleh pengusaha batik berdasarkan hasil wawancara berikut ini;

Pendapatan mengalami peningkatan sekitar 50\% semenjak adanya promosi wisata di Kampung Batik Kauman dan promosi wisata secara individu, karena wisatawan yang datang setelah mengikuti tur wisata dan belajar batik pasti berbelanja. Adanya kegiatan wisata ini juga memberikan keuntungan lain bagi media promosi wisata atau pihak penghubung antara kami sebagai pengusaha batik sekaligus penyedia jasa wisata batik dengan wisatawan seperti hotel, biro perjalanan dan tukang becak, karena setiap ada tamu atau wisatawan yang datang melalui hotel, biro perjalanan dan tukang becak maka media promosi itu akan mendapatkan komisi sekitar 5\% dari total belanja wisatawan yang berbelanja di toko kami. (W/KA/I/2 74-79).

Kegiatan wisata belajar membatik yang dipromosikan telah mampu meningkatkan penjualan batik bagi pengusaha batik dan juga tambahan pendapatan bagi media promosi. Hal ini menunjukkan bahwa dalam sektor pariwisata akan banyak pihak yang terlibat seperti hotel, biro perjalanan dan sektor informal seperti para tukang becak. Peningkatan pendapatan juga terjadi pada rantai nilai produksi batik itu sendiri sehingga semakin banyak wisatawan yang datang semakin banyak pula pendapatan yang diterima oleh para pengusaha batik dan usaha rantai nilai yang mendukungnya seperti yang terungkap dalam wawancara berikut ini;

Industri batik itu mempunyai banyak industri yang tergabung dan menciptakan sebuah rantai nilai, mulai dari proses awal yaitu usaha kain, canting, malam, pewarna, usaha proses seperti konveksi, bordir, aksesoris pakaian, dan usaha pengiriman barang sehingga peningkatan jumlah produksi dan penjualan akan memberikan peningkatan juga bagi industri pendukung (W/IN/P/6 95-113)

Peningkatan pendapatan juga diperoleh oleh para pengusaha batik di Kampung Batik Kauman dan Kampung Batik Pesindon melalui penyediaan homestay. Saat ini sudah ada sebanyak 5\% pengusaha dan masyarakat di Kampung Batik Kauman dan Kampung Batik Pesindon yang menyediakan homestay, hal ini terjadi untuk memenuhi kebutuhan wisatawan terhadap aspek akomodasi karena terdapat paket wisata atau kegiatan wisata belajar batik yang memerlukan waktu lebih dari sehari. Kegiatan wisata kreatif ini mampu memberikan manfaat bagi pengusaha batik dan pelaku usaha pariwisata yang ada di Kota Pekalongan, sehingga melalui pengembangan pariwisata kreatif berbasis industri batik ini diharapkan manfaat yang ada dapat lebih besar dirasakan bagi upaya pengembangan ekonomi lokal Kota Pekalongan. 


\section{Analisis Pertumbuhan Pendapatan Tenaga Kerja Pariwisata Kreatif Berbasis Industri Batik}

Pariwisata kreatif di Kota Pekalongan telah memberikan kesempatan kepada wisatawan untuk dapat berinteraksi dengan pengerajin batik. Selama ini dalam kegiatan wisata kreatif yang ada di Kota Pekalongan, pemandu wisata dan tutor dalam kegiatan wisata belajar batik adalah para pengusaha dan para pengerajin atau pekerja di galeri-galeri batik. Kegiatan wisata kreatif yang ada memberikan pendapatan lebih kepada para pengerajin atau pekerja batik, melalui pemberian komisi bagi pekerja batik yang menjadi tutor dalam kegiatan wisata belajar batik dari hasil pendapatan kegiatan wisata. Peningkatan pendapatan juga terjadi tiap tahunnya, hal ini dikarenakan melalui kegiatan promosi wisata produksi batik dan penjualan batik mengalami peningkatan setiap tahun semenjak adanya kegiatan promosi wisata tersebut, sehingga memberikan peningkatan pendapatan bagi para pekerja industri batik.

Iya ada peningkatan modal, kan untuk membeli canting, kain, wajan yang mau digunakan wisatawan saat wisata belajar batik sama modal untuk biaya tutor, jadi pegawai yang jadi tutor nanti dapat upah juga. (W/PS/I/5 101-104).

Apabila dilihat dari kondisi dua lokasi studi kasus yaitu Kampung Batik Kauman dan Kampung Batik Pesindon yang terdiri dari 50\% pengusaha batik dan 50\% pekerja dan penjual, juga ikut mengalami dampak terhadap kenaikan pendapatan bagi para pekerja batik.Hal ini dikarenakan para pekerja batik memiliki kegiatan lain selain menjadi pekerja di industri-industri batik yaitu dengan melakukan kegiatan pengolahan kain perca sisa industri batik untuk diolah menjadi kerajinan lain seperti taplak meja dan asesoris untuk dijual baik ke toko-toko maupun sebagai cinderamata yang dipamerkan di showroom bersama di masing-masing kampung batik. Kain perca sebagai bahan dasar kerajinan yang diolah oleh para masyarakat pekerja batik ini akan lebih banyak didapatkan apabila industri batik penyedia kain perca mengalami peningkatan produksi. Kondisi ini memperlihatkan adanya saling ketergantungan antar aktivitas. Pengembangan pariwisata kreatif yang berbasis industri batik di Kota Pekalongan menunjukkan adanya manfaat bagi pengembangan ekonomi lokal melalui peningkatan pendapatan bagi para pekerja industri batik.

Berikut ini adalah hasil sintesa dampak yang dirasakan dari adanya penawaran pariwisata kreatif berbasis industri batik Kota Pekalongan.

Tabel 4. Analisis Dampak Aspek Penawaran Wisata Kreatif

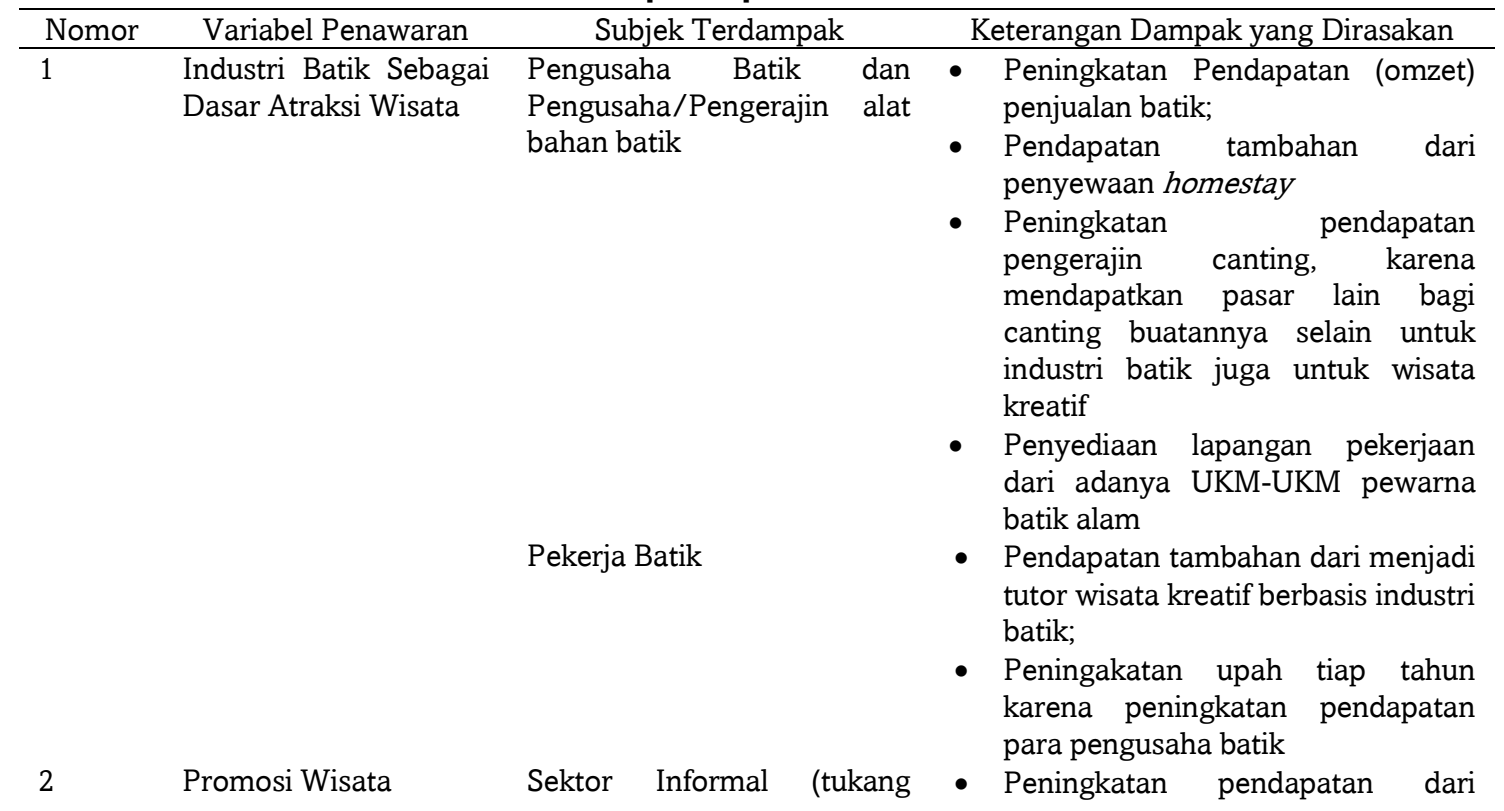




\begin{tabular}{|c|c|c|c|}
\hline Nomor & Variabel Penawaran & Subjek Terdampak & Keterangan Dampak yang Dirasakan \\
\hline & & becak) & $\begin{array}{l}\text { adanya wisatawan yang berkunjung } \\
\text { dan yang menggunakan jasanya ; } \\
\text { Peningkatan pendapatan dari } \\
\text { adanya komisi yang diberikan oleh } \\
\text { para pengusaha karena } \\
\text { mengarahkan wisatawan ke galeri } \\
\text { batiknya }\end{array}$ \\
\hline & & $\begin{array}{l}\text { Jaringan Promosi (Hotel dan } \\
\text { Biro Wisata) }\end{array}$ & $\begin{array}{l}\text { - Mendapatkan sumber pendapatan } \\
\text { lain dari adanya kerjasama dengan } \\
\text { pengusaha batik penyedia jasa } \\
\text { wisata yaitu adanya pemberian } \\
\text { komisi sekitar } 5 \% \text { dari total jumlah } \\
\text { biaya yang dikeluarkan untuk } \\
\text { kegiatan wisata dari wisatawan } \\
\text { yang mereka arahkan. }\end{array}$ \\
\hline 3 & Atraksi Wisata & Masyarakat Setempat & $\begin{array}{l}\text { - Peningkatan pendapatan melalui } \\
\text { penyewaan homestay, pembuatan } \\
\text { souvenir dan jasa pemandu wisata } \\
\text { - Penyerapan tenaga kerja }\end{array}$ \\
\hline
\end{tabular}

Sumber: Hasil Analisis Penulis, 2015

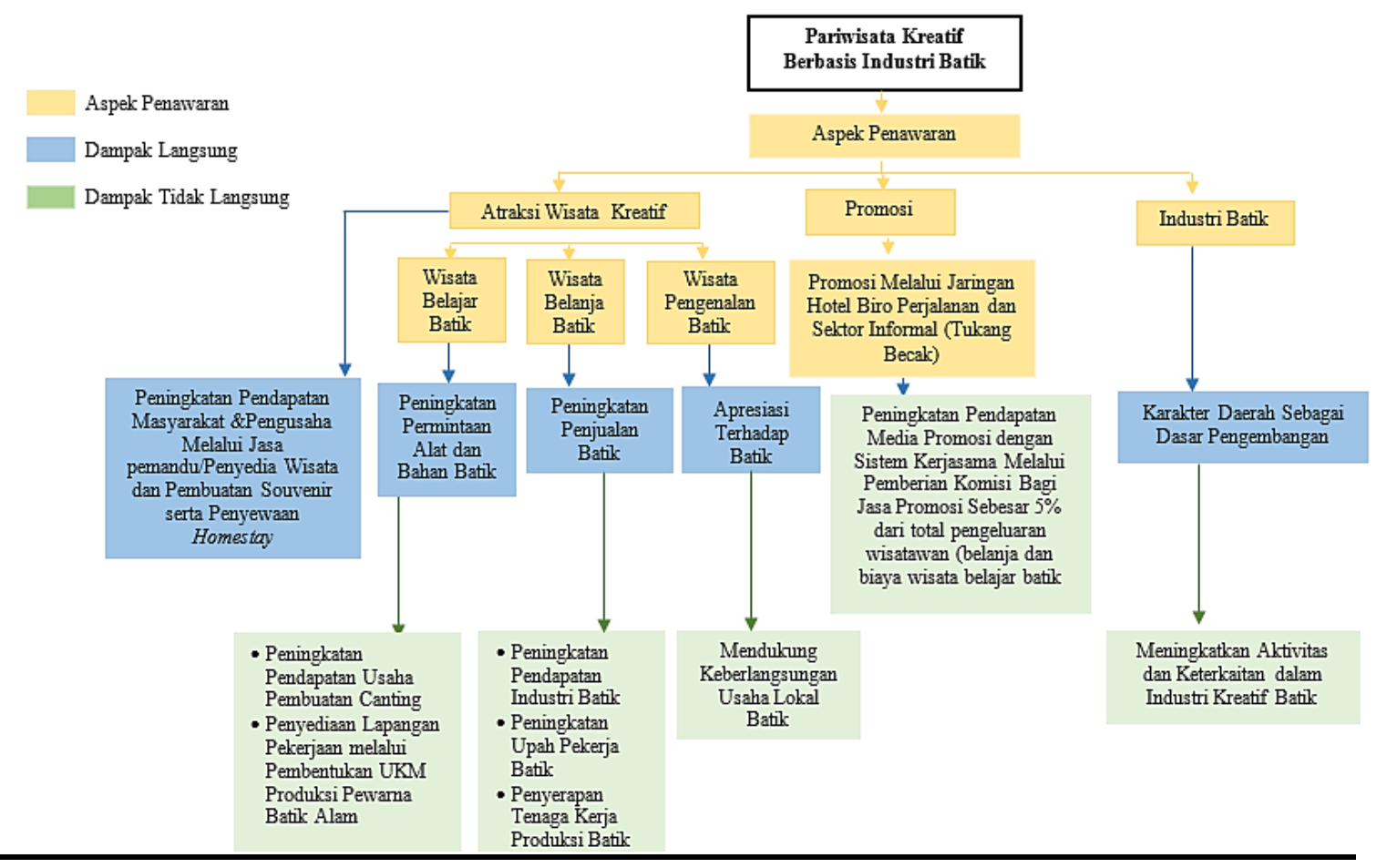

Sumber: Hasil Analisis Penulis, 2015

Gambar 4. Skema Keterkaitan Penawaran Pariwisata Kreatif Berbasis Industri Batik Dengan Pel Kota Pekalongan 


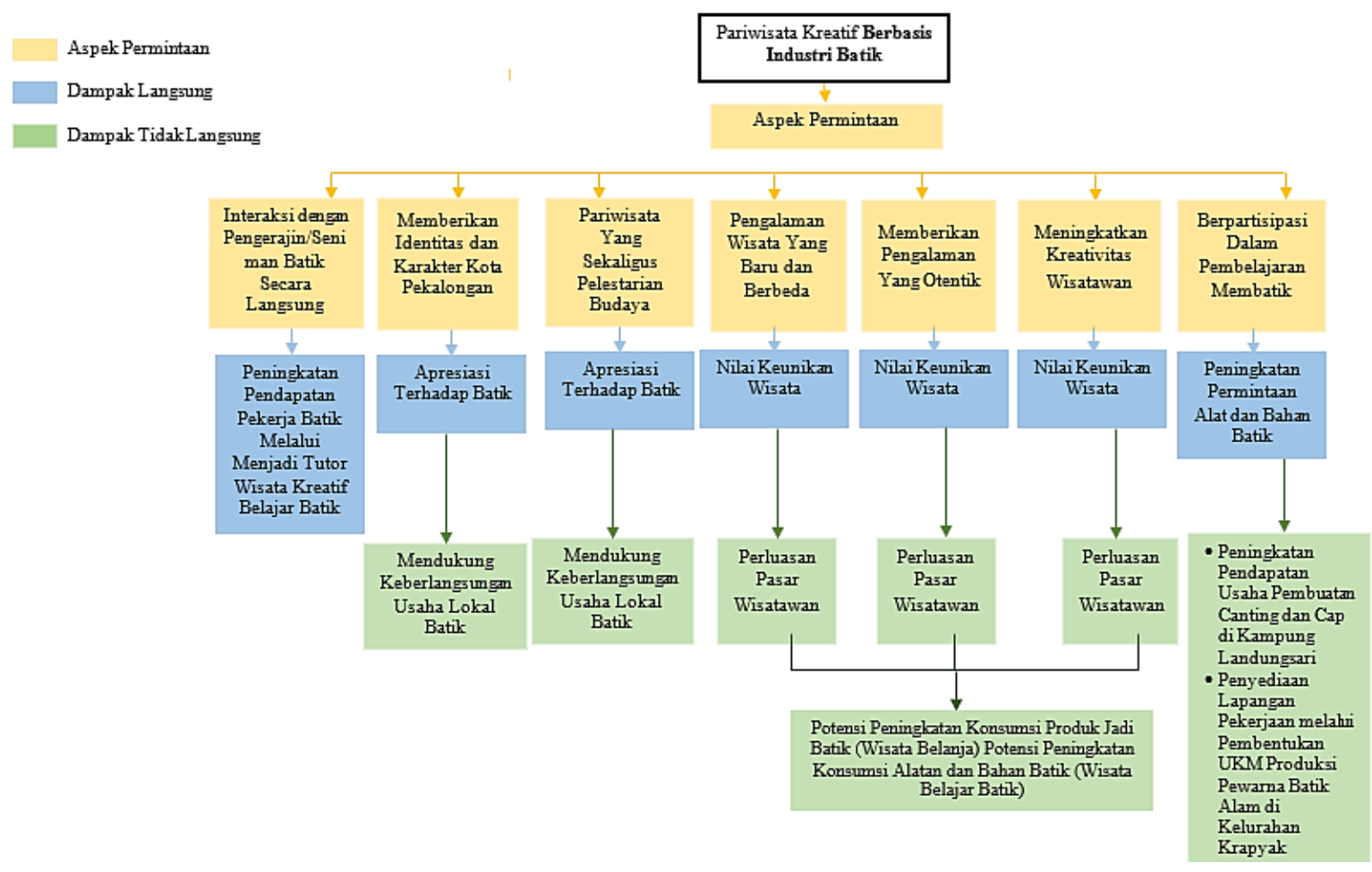

Sumber: Hasil Analisis Penulis, 2015

\section{Gambar 5. Skema Keterkaitan Permintaan Pariwisata Kreatif Berbasis Industri Batik Dengan Pel Kota Pekalongan}

\section{KESIMPULAN}

Melalui atraksi wisata kreatif berbasis industri batik baik berdasarkan aspek penawaran maupun permintaannya, sektor pariwisata yang ada mampu menciptakan dampak yang cukup positif bagi pengembangan ekonomi lokal Kota Pekalongan. Hal ini terjadi dikarenakan industri batik yang menjadi daya tarik wisata merupakan sektor ekonomi yang menjadi lapangan pekerjaan bagi sebagian besar masyarakat Kota Pekalongan. Dilihat dari aspek penawaran dan permintaan wisata kreatif yang ada telah dapat memberikan dampak secara langsung maupun tidak langsung bagi pengembangan ekonomi Kota Pekalongan yaitu diantaranya, peningkatan pendapatan pelaku usaha industri kreatif batik, penyerapan tenaga kerja lokal, peningkatan pendapatan para pekerja industri kreatif dan peningkatan pendapatan bagi pelaku usaha pariwisata. Dampakdampak pariwisata kreatif berbasis industri batik bagi upaya pengembangan ekonomi lokal yang terjadi di Kota Pekalongan diantaranya adalah, peningkatan pendapatan pengusaha batik dari adanya peningkatan penjualan batik akibat dari promosi wisata kreatif dan adanya tambahan pendapatan dari penyedaian jasa wisata kreatif batik bagi wisatawan, peningkatan pendapatan bagi pengusaha batik dan masyarakat melalui penyediaan homestay, peningkatan pendapatan masyarakat melalui kesempatan untuk menjadi pemandu wisata, dan produksi cinderamata wisata, peningkatan pendapatan bagi pengusaha Hotel, Biro Perjalanan dan sektor informal (tukang becak) dari adanya pemberian komisi atas jasa promosi wisata, peningkatan pendapatan bagi pekerja industri 
batik dari jasanya menjadi tutor dalam atraksi wisata kreatif batik, pembukaan lapangan pekerjaan melalui pembentukan kelompok usaha pewarna batik alam untu memenuhi permintaan pewarna baik untuk industri batik maupun untuk kegiatan wisata, serta peningkatan pendapatan usaha pembuatan canting baik untuk memenuhi permintaan industri batik maupun untuk kegiatan wisata

\section{DAFTAR PUSTAKA}

Blair, J. P. (1995). Local Economic Development Analysis and Practice. USA: Sage Publication.

Booyens, I., \& Gustav, V. (2010). Tourism SMME Development on the Urban Fringe: The Case of Parys, South Africa. Urban Forum, 21, 367 - 385.

Creswell, J. W. (2010). Research Design Pendekatan Kualitatif, Kuantitatif dan Mixed. Jakarta: Pustaka Pelajar.

Departemen Perdagangan Republik Indonesia. (2008). Pengembangan Ekonomi Kretaif Indonesia 2025. Jakarta: Departemen Perdagangan.

Ilincic, M. (2014). Benefits of Creative Tourism-Tourist Perspective. Retrieved from https://www.academia.edu/10102778/Benefits_of_Creative_Tourism_The_Tourist_Perspec tive

Incera, A. C., \& Fernandez, M. (2015). Tourism and Income Distribution: Evidence From a Developed Regional Economy. Tourism Management, $11-20$.

Kusworo, H. A. (2009). Pariwisata Untuk Kesejahteraan: Meninjau Ulang Kebijakan Pembangunan. Retrieved from http://www.cpps.or.id/documents/S360_Hendrie Adji Kusworo_Pariwisata untuk Kesejahteraan Meninjau Ulang Kebijakan P

Prasetyo, I. S. (2014). Kajian Aktivitas, Penambangan Minyak Tua dan Pertanian Dalam Upaya Pengembangan Ekonomi Lokal Desa Bangowan Kecamatan Jiken Kabupaten Blora. Semarang.

Richards, G. (2011). Creativity and Tourism, The State Of The Art. Annals Of Tourism Research, 38, 12251253.

Richards, G., \& Wilson, J. (2006). Developing Creativity in Tourist Experiences: A Solution to the Serial Reproduction of Culture. Tourism Management, 27, 1209-1223.

Suparwoko. (2010). Pengembangan Ekonomi Kreatif Sebagai Penggerak Industri Pariwisata. Retrieved from http://dppm.uii.ac.id/dokumen/dikti/files/DPPM-

UII_07._5266_Pengembangan_Ekonomi_Kreatif_Sebagai_Penggerak_Industri_Pariwisata.pdf

Susanti, A. (2013). EtikaPengembangan Ekonomi Lokal Dalam Sektor Pertanian. Jurnal Administrasi Publik, 1, $31-40$.

UNESCO. (2006). Towards Sustainable Strategies for Creative Tourism.

Vesela, D., \& Klimova, K. (2014). Knowledge-based Economy vs. Creative Economy. Procedia Social and Behavioral Science, 141, 413-417.

Wurzburger, R., \& Dkk. (2008). Creative Tourism, A Global Conversation. Santa Fe: Sun Stone Press.

Yoeti, O. A. (2010). Perencanaan dan Pengembangan Pariwisata. Jakarta: Pradaya Paramita. 